\title{
WŁADZA I MEDIA. \\ DYSKURS POLITYCZNY WOKÓŁ MEDIÓW PUBLICZNYCH W POLSCE
}

\section{Stanisław Mocek*}

\begin{abstract}
Abstrakt
Tematyką podjętą w tym tekście jest nakreślenie najbardziej reprezentatywnych opinii i ocen przedstawicieli elit politycznych i medialnych, które można ułożyć w modelowe konstrukcje dyskursywne dotyczące mediów publicznych w polskiej przestrzeni publicznej. Dotyczyć to będzie w przeważającej mierze okresu od grudnia 2015 roku do kwietnia 2016 roku, czyli kluczowego okresu dokonywania radykalnej zmiany w sferze własności i zarządzania mediami publicznymi oraz politycznego, administracyjnego i finansowego nadzoru nad nimi.
\end{abstract}

Słowa kluczowe: mass media, media publiczne, dyskurs publiczny, elity polityczne, partie polityczne

\section{POWER AND MEDIA: Political Discourse on Public Media in Poland}

\begin{abstract}
The aim of this study is to sketch the most representative opinions and assessments of political and media elite representatives, and then place them within the framework of a discourse model regarding public media in the Polish public space. It concerns, principally, the period from December 2015 to April 2016, which constituted the key period of radical change in the sphere of ownership and management of public media as well as political, administrative and financial supervision over them.
\end{abstract}

Keywords: mass media, public media, public discourse, political elites, political parties

\footnotetext{
'Jest to zmodyfikowana i skrócona wersja artykułu, który ukaże się w pracy pod red. Evy Polonska-Kimunguyi i Charlesa Becketta Troubled Democracies and Public Service Media in Europe (Palgrave Macmillan, London 2018) w związku z projektem The Future of Public Service Broadcasting: Poland in a Comparative Perspective, realizowanym w London School of Economics.
}

*Dr hab. Stanisław Mocek, prof. Collegium Civitas, Collegium Civitas, stanislaw.mocek@civitas.edu.pl. 
W Polsce, podobnie jak z różnym natężeniem w innych krajach Europy Środkowo-Wschodniej, od lat 90. ub. wieku media publiczne są przedmiotem sporów i walki politycznej, przynależąc do opcji politycznej będącej aktualnie u władzy (Pokorna-Ignatowicz 2010; Jakubowicz 2008: 101-124. Por. Zielonka 2015). W tym sensie tzw. spoils system rozciągany jest nie tylko na obsadę stanowisk politycznych w administracji państwowej, ale także w sektorze gospodarczym (spółki skarbu państwa) oraz medialnym (media publiczne). Dualny system medialny, obowiązujący w Polsce od początku demokratyzacji i transformacji ustrojowej powoduje, że pluralistyczny charakter tego systemu jest w znacznym stopniu niedoskonały. Sytuacja ta dotyczy także innych rozwiązań dotyczących mediów publicznych w Europie (Public Service Media in Europe: A Comparative Approach 2015)). Komercyjne stacje telewizyjne i radiowe, nawet jeśli nie są bezpośrednio powiązane z konkretnymi partiami politycznymi, zagospodarowują określony segment odbiorców z uwagi na propolityczne i ideologiczne preferencje. Z kolei podstawową przyczyną takiego stanu rzeczy jest też to, że realizacja misji mediów publicznych od początku natrafiała na poważne ograniczenia ze względu na ich znaczne urynkowienie².

Zamierzeniem podjętym $\mathrm{w}$ tym artykule jest nakreślenie mapy najbardziej reprezentatywnych opinii i ocen przedstawicieli elit politycznych i medialnych³, które można ułożyć w modelowe konstrukcje dyskursywne dotyczące mediów publicznych w polskiej przestrzeni publicznej. Dotyczyć to będzie w przeważającej mierze okresu od grudnia 2015 roku do kwietnia 2016 roku, czyli kluczowego okresu

\footnotetext{
${ }^{2}$ Wynika to między innymi z tego, że media, a zwłaszcza telewizja publiczna utrzymuje się w $62 \%$ z reklam i w $30 \%$ z wpływów z abonamentu, a ściągalność jego w porównaniu z innymi krajami jest bardzo słaba (terminowo płaci go niewiele ponad milion gospodarstw domowych; na 13,5 mln gospodarstw domowych w Polsce zarejestrowane odbiorniki ma 6,5 mln, z czego połowa jest zwolniona z tej opłaty ze względu na wiek powyżej 75 lat). Dane na podstawie: Telewizja publiczna w Europie [INFOGRAFIKA] (2016).

3 Elity polityczne rozumiane są tu w znaczeniu tradycyjnym jako przedstawiciele głównych partii politycznych, mających swoją reprezentację parlamentarną, a elity medialne jako reprezentanci mediów głównego nurtu w sferze publicznej.
} 
dokonywania radykalnej zmiany w sferze własności i zarządzania mediami publicznymi oraz politycznego, administracyjnego i finansowego nadzoru nad nimi. Głównymi aktorami uczestniczącymi w tym dyskursie będą politycy, dziennikarze i eksperci, zajmujący się zawodowo refleksją nad mediami w demokratycznym porządku politycznym. W artykule tym zidentyfikowane zostały główne osie podziałów, dotyczących stosunku do mediów publicznych, które są pochodną programowych różnic między elitami politycznymi w zakresie konstrukcji państwa i systemu medialnego.

Artykuł podzielony został na trzy części. Pierwsza, poświęcona jest nakreśleniu historycznego tła, dotyczącego relacji między systemem medialnym a systemem politycznym po 1989 roku, ze szczególnym uwzględnieniem mediów publicznych w tych systemach. W drugim uwaga poświęcona została dyskursowi publicznemu jako metodzie badawczej, która zastosowana została do przeprowadzenia analizy, dotyczącej stosunku elit do sprawy mediów publicznych. I trzeci, w znacznej części empiryczny, stanowi prezentację debaty politycznej wokół mediów publicznych w latach 2015-2016, w szczególności między grudniem a kwietniem, czyli kluczowym momencie dokonywania zasadniczych zmian $\mathrm{w}$ tym zakresie.

System medialny a system polityczny w Polsce po 1989 roku i rola mediów publicznych

Bogusława Dobek-Ostrowska wskazuje na cztery etapy tworzenia demokratycznego systemu medialnego: etap wstępny dokonujący się w fazie przygotowawczej (w Polsce dotyczy to czasów sprzed 1989 r.): etap podstawowy w okresie przejścia do demokracji, etap wtórny w okresie konsolidacji demokracji i etap dojrzałości mediów, który odpowiada dojrzałej demokracji (Dobek-Ostrowska 2010, s. 17; por. Media Reform. Democratizing the media, democratizing the state 2002). Jeśli 
uznać pluralizm za podstawową wartość mediów w demokracji, to z punktu widzenia rynkowego spojrzenia na system medialny, sytuacja mediów elektronicznych w Polsce odpowiada standardom dojrzałej demokracji. Podobnie jest z całkowicie wolnym rynkiem mediów prasowych. Jednak z punktu widzenia wewnętrznych uwarunkowań związanych z sytuacją mediów publicznych w tym systemie wciąż dotyczy to fazy podstawowej lub wtórnej, kiedy nie obowiązują przejrzyste zasady pluralizmu w mediach publicznych, wyrażające się w sferze organizacji i zarządzania nimi, ale przede wszystkim oferty programowej zgodnej z misją tychże mediów oraz spraw personalnych, dotyczących przede wszystkim pluralistycznego doboru dziennikarzy.

Po 1989 roku przekształcenia ustrojowe w Polsce objęły także polskie radio i telewizję, które po okresie mediów państwowych podlegających partii komunistycznej i rządowi oraz urzędowi cenzury stały się mediami publicznymi. Z kolei od 1992 roku zaczął kształtować się także komercyjny rynek mediów elektronicznych, regulowanych w drodze koncesji wydawanych przez konstytucyjnie umocowaną Krajową Radę Radiofonii i Telewizji. Przez cały ten okres skład KRRiT, a w konsekwencji także skład zarządów publicznego radia i telewizji zależne były od sytuacji politycznej w Polsce i ulegały zmianom w zależności od aktualnego układu sił w parlamencie. Władze tych instytucji i realizowana przez nie linia programowa uzależnione były zatem od większości parlamentarnej. Kilkakrotnie nowelizowane akty prawne dotyczące tych regulacji nie doprowadziły do zasadniczych zmian tej sytuacji. W wyniku tej sytuacji, przez ponad dwadzieścia lat, kolejne, następujące po sobie rządy - liberalne, lewicowe czy konserwatywne - zdaniem zdecydowanej większości komentatorów, dziennikarzy i polityków, a także opinii publicznej nie dokonały zasadniczych zmian w funkcjonowaniu mediów publicznych, zgodnych z zasadami pluralizmu, dotyczącego oferty programowej i doboru kadry dziennikarskiej. 
Wśród postulatów wyborczych, w którymi szło do wyborów w 2015 roku Prawo i Sprawiedliwość znajdowały się także te zawierające krytyczny stosunek do mediów publicznych (Program Prawa i Sprawiedliwości 2014). Dotyczyły one przede wszystkim zarzutu o nierespektowanie pluralizmu w prezentowaniu poglądów różnych opcji politycznych, skrajną komercjalizację przede wszystkim telewizji publicznej i niewywiązywanie się z nałożonej na nią misji nadawcy publicznego. Zapowiadano wówczas przekształcenie mediów publicznych w instytucje kultury, jednoosobowe zarządy tych instytucji wybierane spośród autorytetów świata kultury, finansowanie w 75\% ze środków publicznych, zatrzymania monopolizacji mediów przez kapitał zagraniczny, ograniczenie reklam, zdominowanie oferty programowej kulturalną i obywatelską edukacją odbiorców (Por. Rutkowska 2015).

Należy przypomnieć, że już podczas pierwszych rządów PiS z Samoobroną i Ligą Polskich Rodzin, w roku 2005 i 2009 podejmowano próby legislacyjnych zmian dotyczących mediów publicznych, ale okazały się one nieskuteczne. Udało się to zrealizować w drodze nowelizacji ustawy o radiofonii i telewizji dopiero w grudniu 2015 roku, po wygranych wyborach prezydenckich i parlamentarnych, w wyniku których po raz pierwszy od 1989 roku jedna partia uzyskała większość parlamentarną pozwalającą na samodzielne stworzenie rządu4. Odstąpiono wówczas od szerszych konsultacji społecznych czy środowiskowych związanych ze zmianami prawnymi. W takim też trybie przeprowadzono nowelizację prawa medialnego, a głównymi założeniami tej nowej regulacji stało się powoływanie o odwoływanie nowych członków zarządów TVP i PR

\footnotetext{
4 W wyniku wyborów parlamentarnych, przeprowadzonych 25 października 2015 roku, do sejmu dostało się 6 partii lub koalicji wyborczych. Na 460 miejsc narodowo-konserwatywne Prawo i Sprawiedliwość zdobyło 235 mandatów. Kolejne miejsca zajęły następujące ugrupowania: liberalna Platforma Obywatelska (138 mandatów), która sprawowała przez 8 lat rządy koalicyjne z partią agrarną Polskim Stronnictwem Ludowym (16 mandatów); po raz pierwszy do sejmu weszły: narodowy Komitet Wyborczy „Kukiz'15”, piosenkarza rockowego Pawła Kukiza (42 mandaty) i liberalny Komitet Wyborczy Nowoczesna ekonomisty Ryszarda Petru (28 mandatów). Po raz pierwszy od 1989 roku do sejmu nie weszło żadne ugrupowanie lewicowe.
} 
przez ministra skarbu bez kadencyjności, skrócenie dotychczasowych kadencji i natychmiastowe wygaśnięcie mandatów członków zarządu i rad nadzorczych; utrata przez KRRiTV szeregu kompetencji związanych z kontrolą nad mediami publicznymi (likwidacja konkursów na stanowiska w zarządzie i uprawnień do wyrażania zgody na zmianę statutów spółek). Oznaczało to przejęcie nadzoru nad publicznym radiem i telewizją przez rząd.

Debata sejmowa dotycząca tej nowelizacji odbyła się pośpiesznie, późną porą 29 i 30 grudnia przy pustych ławach rządowych, co w wielu wystąpieniach podnosili posłowie opozycji5. Wbrew temu co jeszcze w styczniu 2016 oficjalnie podawali politycy $\mathrm{PiS}^{6}$ sprawdziły się zatem opinie opozycji, że szybkie tempo wprowadzanych zmian, bez konsultacji i debaty publicznej podporządkowane było doraźnym celom politycznym, wśród których najważniejszym było przejęcie pełnej kontroli nad mediami publicznymi w celu dysponowania wpływem nad opinią publiczną poprzez jeden z najważniejszych nośników masowego przekazu.

Oprócz sporu politycznego, który dominował w 2016 roku narastał kryzys finansowy tych mediów, zwłaszcza telewizji, a bezpośrednią konsekwencją tej politycznej destabilizacji jest spadek oglądalności, przede wszystkim kluczowych programów informacyjnych. Na przykład

\footnotetext{
5 W podobnej konwencji i nagłej atmosferze przebiegało zresztą wiele innych zmian legislacyjnych, zwłaszcza na przełomie 2015 i w 2016 roku: napięta sytuacja, związana z Trybunałem Konstytucyjnym i sektorem sądownictwa, zmiana systemu oświatowego, służby cywilnej, zmiana systemu emerytalnego i w wymiarze sprawiedliwości. Działania związane z tzw. „małą ustawą medialną”, określane jako prowizoryczne, zgodnie z przewidywaniami okazały się na tyle trwałe, że rozwiązania w niej zawarte okazały się obowiązujące na cały rok 2016 i 2017.

${ }^{6}$ Taka informacja przekazywana była wielokrotnie przez wpływowych polityków PiS. Między innymi posłanka Prawa i Sprawiedliwości, Barbara Bubula, która pracowała w ścisłym zespole nad projektem nowelizacji ustawy medialnej mówiła o tym zaraz po uchwaleniu nowelizacji: „Ustawa o dużej zmianie jest już gotowa. Potrzebujemy kilku tygodni, maksymalnie dwóch miesięcy, żeby dokonać notyfikacji przepisów do Komisji Europejskiej i przeprowadzić konsultacje społeczne. Wydaje nam się, że tak poważna zmiana nie może odbyć się bez tych dwóch elementów. W nowelizacji chodzi o uspokojenie sytuacji, ponieważ stan bardzo dużego wzmożenia politycznego w mediach w oczekiwaniu na dużą ustawę nie działało pozytywnie na spokój konsultacji oraz dobre przygotowanie projektu. W Prawie i Sprawiedliwości zapadła zbiorowa decyzja o tym, żeby w taki sposób tę reformę przeprowadzić" (cytat za: Brzezicki 2016).
} 
w okresie nowelizacji ustawy o radiofonii i telewizji (przełom 2015 i 2016 roku) segment rynku telewizyjnego w Polsce przedstawiał się następująco: publiczna telewizja TVP 1 (945 tys. średniej oglądalności) i TVP 2 (636 tys.) i TVP IINFO (286 tys.), komercyjne: Polsat (816 tys.) i TVN (769 tys.) (Media w Polsce. Do kogo należy prasa, telewizja, portale czy radio? 2016)7 Ale już w czerwcu 2017 roku nastąpiła wyraźna zmiana: publiczna telewizja TVP 1 (506 tys. średniej oglądalności) i TVP 2 (359 tys.) i TVP INFO (223 tys.), komercyjne: Polsat (622 tys.) i TVN (509 tys.). Jeszcze bardziej znaczące różnice zachodziły w widowni stacji publicznych w przedziale wieku od 16 do 49 lat (Pallus 2017).

Wskutek tak drastycznego spadku oglądalności w telewizji publicznej i zanotowanej straty finansowej za 2016 rok, podjęto na początku 2017 roku intensywne działania prawne na rzecz zwiększenia ściągalności abonamentu. Jednak w połowie tego roku rząd zawiesił je wskutek oporu operatorów sieci telewizyjnych i niekorzystnego odbioru społecznego takich rozwiązań (tw 2017). Także państwowa instytucja GIODO (Główny Inspektor Ochrony Danych Osobowych) zgłosiła wobec nowelizacji sporo uchybień związanych z poufnością i przetwarzaniem informacji o danych osobowych polskich obywateli (tw 2017a). Jednocześnie, w celu ratowania budżetu telewizji publicznej pojawiły się informacje o zaciągniętym kredycie na działalność telewizji publicznej w kwocie 800 mln zł (oprac. Bereźnicki 2017).

Należy wspomnieć, że pół roku po wspomnianej wcześniej nowelizacji został przyjęty projekt tzw. dużej ustawy medialnej, czyli pakiet trzech aktów prawnych autorstwa PiS: o mediach narodowych, składce audiowizualnej i projekt przepisów wprowadzających te dwie ustawy. W ramach tych zmian TVP, Polskie Radio i Polska Agencja Prasowa miały zostać przekształcone w instytucje mediów narodowych. Wyboru

7 W tym samym materiale znajdują się także dane dotyczące udziału w rynku stacji radiowych, ale w przypadku radia nie mamy do czynienia z tak zauważalnym spadkiem słuchalności ze względu na większe rozdrobnienie rynku radiowego. 
władz mediów narodowych dokonywałaby Rada Mediów Narodowych wybierana przez Sejm, Senat i prezydenta na 6-letnią kadencję. „Duża” ustawa medialna miała wejść w życie 1 lipca 2016 roku, ale odłożono ją w czasie z powodu zakresu zmian, który musi notyfikować Unia Europejska. Ale 7 lipca 2016 roku weszła w życie ustawa o Radzie Mediów Narodowych, której zadaniem ma być powoływanie i odwoływanie zarządów i rad nadzorczych TVP, Polskiego Radia i Polskiej Agencji Prasowej (po wyborze Rady, TVP, PR i PAP nie podlegają już ministrowi skarbu). W skład Rady Mediów Narodowych wchodzi pięć osób.

Sytuacja ciągłego upolitycznienia i upartyjnienia mediów publicznych, obecnie zgodnego z linią polityczną i ideologiczną jednej partii politycznej powoduje, że cały system medialny w Polsce ulega od lat polaryzacji według dwubiegunowego podziału sfer wpływu na opinię publiczną. Główna oś tej fragmentacji zaczyna przebiegać według kryterium bycia „za” lub „przeciw” aktualnej władzy. Zarówno mała, jak i duża ustawa medialna konserwuje tylko ten stan rzeczy, co powoduje, że w dalszym ciągu oddala się wizja faktycznie pluralistycznych mediów publicznych. Od lat takim idealnym wzorcem mediów publicznych przedstawiany jest przykład BBC i przy wielu okazjach w debacie publicznej to właśnie BBC uznawane jest za modelowy przykład rzetelnego i obiektywnego, pluralistycznego nadawcy publicznego. Często przy takich okazjach podkreśla się obywatelski charakter takiego nadawcy, przez co rozumie się przeniesienie właścicielskich uprawnień nad mediami publicznymi na ciała społeczne (np. organizacje medialne i dziennikarskie, instytucje akademickie), a nie polityczne, a tym bardziej państwowe czy rządowe.

Tym wszystkim, scharakteryzowanym tu bardzo pobieżnie zjawiskom i wydarzeniom politycznym towarzyszy specyficzne zagospodarowanie przestrzeni dyskursywnej, charakteryzującej się operowaniem przez głównych aktorów życia publicznego schematami językowymi i komu- 
nikacyjnymi, charakterystycznymi dla głębokiego podziału społecznego, który dokonywał się w Polsce w ostatnich latach, szczególnie po katastrofie smoleńskiej.

\section{Dyskurs publiczny $\mathrm{i}$ jego odmiany}

Tematyka dyskursu publicznego i podejmowane metody badawcze w tym zakresie należą do kluczowych zagadnień sfery publicznej i technik jej badania.

Dyskurs, w powszechnym odbiorze i skojarzeniu to rozmowa, mowa, wystąpienie, dyskusja lub też uporządkowana lub spontaniczna wymiana informacji. Rzeczywistość dyskursywna zatem jest wytwarzana jako pewien fragment rzeczywistości, będący w stanie procesu, usytuowany w procesie negocjowania znaczeń słów i tekstów między co najmniej dwoma jego uczestnikami, lub też grupami społecznymi, etnicznymi, politycznymi lub kulturowymi. Właściwości przynależne temu procesowi stały się podstawą dla ukształtowania się dwóch podstawowych koncepcji dyskursywnych: lingwistycznej i socjologicznej.

Według tej pierwszej, dyskurs jest przede wszystkim kategorią językową, a ściślej mówiąc, tekstową, tzn. jest zdarzeniem tworzącym tekst. Drugie podejście, znacznie bliższe podejmowanej tu problematyce odnosi się najczęściej do badań nad kształtowaniem się i przebiegiem interakcji w społeczeństwie. Na przykład Michel Foucault proponuje zdefiniowanie dyskursu jako przekazywanie idei i oddziaływanie na ludzi za pomocą języka, mocno uwarunkowane usytuowaniem społecznym nadawców i odbiorców, celami i potrzebami, stanem wiedzy, zestawem i hierarchii wartości, a także społecznym kontekstem komunikowania oraz specyficznego komunikacji za pośrednictwem mediów masowych (Por. Foucault 1977; Lisowska-Magdziarz 2006).

Do tej właśnie koncepcji dyskursu, określającej przedmiot badań jako wypowiedź oraz tekst w kontekście nawiązuje jeden z głównych 
teoretyków i badaczy zjawisk komunikacyjnych metodą krytycznej analizy dyskursu, Teun van Dijk (1997: 12). Zatem refleksja nad dyskursem oznacza ukierunkowanie analizy na kontekstowe, pozajęzykowe treści komunikatu, wpływające na jego znaczenie. Podsumowując, pojęcie dyskursu w naukach społecznych można zdefiniować jako prowadzenie badań nad językiem w kontekście społecznym, jako nie tylko utrwalony system znaków, ale również szerszy kontekst jego powstania.

Czołowy polski badacz dyskursu, Marek Czyżewski, wyróżnia trzy główne jego odmiany: publiczny, dyskurs polityki i dyskurs polityczny, uznając za nadrzędny ten pierwszy (Czyżewski et. al. 1997: 21; Czyżewski 1997: 42-118). Autor zalicza do niego wszelkie przekazy dostępne publicznie: dyskursy instytucjonalne, prowadzone przez instytucje pełniące usługi publiczne (urzędy, szkoły, sądy), dyskursy związane z określonymi grupami społecznymi (dyskurs literacki, biznesowy) oraz dyskursy medialne. $Z$ kolei dyskurs polityki to część dyskursu publicznego, rozumiana jako wypowiedzi osób należących do elity władzy, związane z pełnionymi przez te osoby rolami i funkcjami politycznymi. Marek Czyżewski dyskurs polityczny definiuje szerzej jako proces komunikacji elit symbolicznych, czyli grup i osób, które sprawują władzę nad środkami komunikowania masowego, przede wszystkim dziennikarzy i polityków, którzy występują w podwójnej roli (należą do elit symbolicznych, a niektórzy z nich są przedstawicielami elit władzy). Autor proponuje też mianem dyskursu politycznego określać wszelkie zdarzenia komunikacyjne rozpoczęte i rozwijane w ramach dyskursu elit symbolicznych, ale dotyczących tylko obszaru tematycznego związanego z polityką. Dyskurs polityczny spełnia szczególną rolę w kształtowaniu rzeczywistości społecznej i integrowaniu zachodzących w niej praktyk komunikacyjnych.

Zaprezentowana w tym artykule charakterystyka dyskursu medialnego w polityce i dyskursu politycznego w mediach jest optymalną perspektywą badawczą. Tworzy ona ramy metodologiczne do analizy 
dyskursu politycznego wokół debaty o mediach publicznych toczonej głównie przez polityków i dziennikarzy jako przedstawicieli elit symbolicznych. Z tego punktu widzenia najbliższą metodą analizy dyskursu w niniejszym tekście jest ta, którą reprezentuje właśnie Marek Czyżewski. Decyduje o tym, z jednej strony pojemność metodologiczna, polegająca na badaniu dyskursu publicznego, włączając w to dyskurs polityczny i dyskurs polityków, po drugie kontekstualny aspekt dyskursu, wykraczający znacznie poza badanie jedynie treści wypowiedzi.

Debata polityczna wokół mediów publicznych 2015-2016

Punktem wyjścia do analizy dyskursu politycznego wokół mediów publicznych była debata, która odbyła się w polskim parlamencie podczas przyjmowania w trybie przyśpieszonym nowelizacji ustawy o radiofonii i telewizji w końcu grudnia 2015 roku.

Przeanalizowanych zostało łącznie ok. 200 wypowiedzi polityków, dziennikarzy, komentatorów politycznych i ekspertów medialnych, prasowych i internetowych. Wszystkie wypowiedzi posłów oparte są na stenogramie z 7 posiedzenia Sejmu RP z grudnia 2015 roku (Sejm RP 2015; Sejm RP 2015a), a inne cytaty pochodzą z badania autora przeprowadzonego przy pomocy zebranych tekstów przez Instytut Monitorowania Mediów w kwietniu i maju 2017 roku. Podczas analizy zwracano uwagę przede wszystkim na argumentację i ocenę dotyczącą dokonywanej zmiany legislacyjnej. Wybrane zostały te najbardziej charakterystyczne i reprezentatywne wypowiedzi, które pozycjonowały stosowaną argumentację w tej sprawie w określonym segmencie dyskursywnym. O wyborze decydowała w znacznej mierze powtarzalność argumentacji, a na szczególną uwagę zasługiwały zarówno podobieństwa stanowisk, ale przede wszystkim te różnice, które układały się w opozycyjne schematy poznawcze. 
Podobnej analizy wystąpień posłów reprezentujących różne kluby parlamentarne w sprawie mediów publicznych dokonuje Magdalena Wnuk (2016, ss. 77-92). Twierdzi ona, że podczas tej debaty można było zauważyć kilka dominujących dyskursów polityków różnych partii politycznych charakteryzujących media publiczne: 1. PiS: chrześcijańskie i narodowe, zgodne z polską racją stanu, przekazują prawdę, obiektywne, rzetelne; 2. PO: fundament demokracji, wolne, niezależne; 3. Kukiz'15: misyjne, obywatelskie, narodowe, odpartyjnione; 4. .Nowoczesna: publiczne, obywatelskie, apolityczne, bezstronne, wzorowane na BBC; 5. PSL: niezależne, jawnie zarządzane.

Na użytek przeprowadzanej tu analizy dyskursu warto podzielić te wypowiedzi według trzech kategorii, odpowiadających sposobowi myślenia o mediach publicznych i dokonywanej zmianie. Wystąpienia polityków podczas tej debaty sejmowej uzupełnione zostaną wypowiedziami innych osób: ekspertów, dziennikarzy i komentatorów. Będzie to $\mathrm{w}$ tym przypadku zgodne z przyjętą w tym artykule metodą badawczą polegającą na analizie dyskursu politycznego, w którym znajdują się wątki dyskursu polityków i dyskursu politycznego w mediach.

Analiza wszystkich wypowiedzi wyłoniła trzy modele dyskursywne, dominujące $w$ debacie publicznej we wskazanym okresie: 1) model rewolucyjny „dobrej zmiany”; 2) model zemsty i odwetu; 3) model mediów obywatelskich.

Model rewolucyjny „dobrej zmiany”

Model pierwszy usytuowany jest w przeważającej mierze w oparciu o założenia nurtu narodowo-konserwatywnego, reprezentowanego przez PiS. Szczególną uwagę zwraca tu stawianie przez PiS wyraźnej cezury między okresem sprzed 2015 roku i po, przy czym niejednokrotnie krytyka przeszłości odnosi się nie tylko do ośmioletniego okresu rządów

\footnotetext{
${ }^{8}$ Hasło wyborcze Prawa i Sprawiedliwości w kampanii wyborczej do parlamentu w 2015 roku.
} 
PO, ale i początków transformacji ustrojowej. Kontestacja tej periodyzacji ma swój początek w odniesieniu do zarzutu porozumienia części elit wywodzących się z nurtu opozycyjnego z komunistami podczas „okrągłego stołu”. Jest to zamierzony zabieg propagandowy stosowany często przez partię PiS do negowania osiągnięć i kontestowania całego okresu przemian demokratycznych w Polsce po 1989 roku, co znajduje wyraz w określaniu całego tego przedziału czasowego mianem „postkomunizmu”. Podobny zabieg stosowany był przez tę partię w latach 2005-2007, kiedy w celu wyraźnego odcięcia się od poprzedniego okresu - klasyfikowanego jako III RP - zastosowano konstrukt budowania IV RP. Działania te, odbywające się i w sferze symbolicznej, ale i realnej, w wyniku rozpadu ówczesnej trójpartyjnej koalicji zakończyły się po dwóch latach przedterminowymi wyborami parlamentarnymi, przegranymi przez PiS (Śpiewak 2010).

Aby zrozumieć mechanizm tych zmian, należy cofnąc się do roku 2005, bowiem pewien zasadniczy schemat myślenia niemal w całości uległ transmisji na rok wyborczy 2015. Postulat wprowadzenia nowego porządku budowany był w oparciu o przesłanie politycznego działania polegającego na „walce”: walce z dziedzictwem III RP, walce z siłami starego porządku, walce polegającej na rozliczeniu czasów komunistycznych, walce z szeroko pojętym „układem”: tajnymi współpracownikami SB z czasów PRL, siłami specjalnymi o rodowodzie komunistycznym, nomenklaturowym światem finansowym i aferalnym biznesem, światem mediów i wielkich, obcych koncernów medialnych (Ibidem).

Dominowała retoryka rozbicia tego układu, którego poszczególne elementy nawzajem się wspierają i powodują rozkład instytucji państwowych i samego państwa, korupcję, obniżenie standardów w polityce wewnętrznej i pozycji Polski w świecie. „Partia Jarosława Kaczyńskiego - pisał w „Polityce” już dekadę temu Janicki i Władyka - to chyba jedyne już w Europie znaczące ugrupowanie głównego nurtu, którego celem jest rewolucja, zmiana prawa, systemu wartości, rewizja historii, 
rozliczenie $\mathrm{z}$ ideologicznym wrogiem, nawet kosztem praw jednostki, wprowadzenie jednej normy kulturowej i wspólnotowej, obowiązującego wzorca patriotyzmu. To jest nurt dokładnie przeciwny tendencjom, jakie dziś dominują w Europie, ale PiS także z tego robi atut na zasadzie, iż czasami uświadomiona mniejszość ma rację. Zatem wszystko trzeba rozpocząć od nowa, założyć nową Rzeczpospolitą. Rewolucję w wydaniu PiS cechowała nowa polityka historyczna, specyficzna antyinteligenckość (z pewną liczbą inteligentów »słusznych «; nienawiść do wroga: klasowego (oligarchowie), korporacyjnego (prawnicy, lekarze, nauczyciele akademiccy). Stare elity (jak za PRL te przedwojenne) i salony miały zostać rozbite i skompromitowane, a na ich miejsce miały przyjść nowe" (Janicki, Władyka 2009: 10).

Program tworzenia nowego porządku społeczno-politycznego, oparty na retoryce rewolucyjnych zmian forsowanych przez PiS, budowany był w opozycji już nie tylko do systemu komunistycznego, ale także procesu demokratyzacji lat 9o. i początku XXI wieku.

Polityczna filozofia i ideologia PiS-u osadzona jest zatem na rewizji nie tylko najnowszej historii politycznej czasów wojennych i powojennych oraz okresu PRL, ale też początków transformacji, systemowego przełomu i ustrojowego punktu odniesienia z tego okresu. Czas transformacyjny według tych założeń nie zaczyna się wcale w 1989 roku; rok 1989 nie był według PiS triumfem przełomu ustrojowego, ale taktycznym i strategicznym porozumieniem elit, służącym zakonserwowaniu „układu” ekonomicznego i politycznego nomenklatury komunistycznej z niereprezentatywnym dla całości opozycji odłamem obozu solidarnościowego. Był to okres symbolicznie wyrażany jako III RP. Stąd niekończący się spór o „prawdziwych bohaterów” i jedynie uzurpatorów zwycięstwa nad komunizmem, o prawdziwą i zafałszowaną wersję walki opozycji demokratycznej z lat 70., pierwszej Solidarności i opozycji po stanie wojennym z lat 8o. zeszłego wieku 
W takim kontekście sektor mediów publicznych - zdaniem wielu działaczy związanych w PiS - jest jednym z wielu, który podlegał tym niekorzystnym zmianom i w tym celu należy dążyć do jego szybkiej zmiany. Towarzyszą temu czysto praktyczne i pragmatyczne cele, polegające na przejęciu ważnego narzędzia propagandowego do realizacji celów politycznych, z którymi PiS dążył do władzy i dzięki którym wygrał wybory prezydenckie i parlamentarne w 2015 roku. Publiczne media są znaczącym graczem na rynku medialnym w Polsce i ich wykorzystanie do umocnienia władzy jest zjawiskiem niezaprzeczalnym z punktu widzenia ćwierćwiecza praktyki politycznej w tym zakresie.

Pierwszy typ myślenia i argumentacji, reprezentowany przede wszystkim przez przedstawicieli strony rządowej kładzie szczególny nacisk na narodowy charakter takich mediów i polską rację stanu. Jest to przede wszystkim zabieg retoryczny, mający wymiar deklaratywny, charakterystyczny dla czarno-białego przekazu propagandowego. Ale ma on też dwa wymiary: jeden dotyczący spraw własności nad tymi mediami i tu „narodowe” rozumiane są przede wszystkim jako państwowe, a drugi, właśnie związany z odpowiednią otoczką retoryczną, podkreślający „służbę narodowi”.

W tej klasie wypowiedzi występuje kilka charakterystycznych wątków, odnoszących się przede wszystkim do: 1) diagnozy całej sytuacji, zdecydowanie negatywnej, która ma być wystarczającym powodem do dokonania radykalnych zmian, 2) powoływania się na „autentyczną opinię publiczną” i „mody nieakceptowane przez większość społeczeństwa” - wątki bardzo trudne do zweryfikowania i polegające na prostym przełożeniu większości parlamentarnej na większość społeczeństwa; z tego powodu PiS ma legitymację do dokonania takich gruntowych przeobrażeń. Następnym elementem jest zarzut o „hołdowaniu politycznej poprawności” - przeciwieństwem politycznej poprawności może być tylko przekonanie o nieomylności dziejowej PiS, jedynie słusznej i obowiązu- 
jącej wśród większości społeczeństwa oraz przekonanie o tym „co decyduje o bycie milionów Polaków i naszego państwa” - tylko PiS ma poparcie ludu i potrafi odczytać jego potrzeby; z założenia poprzednia władza była nieczuła na te oczekiwania. Elementem spinającym wszystkie powyższe argumenty jest przeświadczenie posłów PiS-u o „racji stanu” - racją stanu jest racja jednej partii i jednego dominującego punktu widzenia przez nią reprezentowanego, a media publiczne ma tej racji stanu służyć.

W innych wystąpieniach pojawia się motyw porównywania stanu zastanego do planowanego, według kilku bardzo dosadnie wyrażonych opinii, ułożonych według schematu: prawda-kłamstwo, media narodowe-partyjne, dziennikarze-funkcjonariusze medialni, media rzetelnie informujące-media będące tubą partii rządzącej.

W tym nurcie dyskursywnym dominuje walka przeciwieństw i czarnobiały schemat argumentacyjny. „Nowe”, będące częścią „dobrej zmiany” rywalizuje ze „starym”, patologicznie upartyjnionym, według działacza PiS, układem. W tym celu dyspozycyjni dziennikarze muszą zostać tymi, którzy reprezentują - jak to charakteryzowała wcześniej Kruk - polską rację stanu, „akceptowaną” przez większość społeczeństwa. Mimo deklaracji o przywróceniu uczciwości rzetelności w mediach, w nikłym stopniu ma tutaj miejsce postulat całkowitego odpartyjnienia mediów, bowiem gołym okiem, już podczas tej debaty było widać, że jest to wariant zastąpienia jednej ekipy politycznej przez drugą, która uzurpuje sobie prawo do występowania w imieniu rzekomo „autentycznej” opinii publicznej.

Ponadto w wypowiedziach tych, tylko pozornie sprzeczne jest z jednej strony odwoływanie się do mediów jako „ważnego narzędzia państwa” i temu, aby „polskie media służyły polskiemu społeczeństwu”. Bowiem filozofia PiS zakłada nadrzędność państwa nad społeczeństwem; tylko silne państwo może wpływać na rozwój społeczeństwa i jego różnych 
grup. $Z$ tego punktu widzenia tylko media narodowe, czyli de facto państwowe, służą realizacji prospołecznej misji.

Można więc przyjąć, że stosując analogiczny wzorzec do tego, który dotyczy klasycznego spojrzenia na elity polityczne, zamiast cyrkulacji lub reprodukcji elity mamy do czynienia z mechanizmem całkowitej ich wymiany w imię rewolucyjnych haseł i dążenia do radykalnej zmiany systemowej. I tu przechodzimy do kwestii, podnoszącej rolę elit.

Model wymiany elit medialnych w ramach odwetu i zemsty

I tu mamy do czynienia z modelem drugim, w którym eksponowane są przede wszystkim elementy zmiany w sferze mediów publicznych, wynikających z walki politycznej. Dominuje w tym wypadku schemat myślenia polegający nie tyle na walce starego z nowym rozwiązaniem sprawy mediów publicznych, ale wyłącznie na wymianie jednej ekipy na drugą. To między innymi powoduje, że nie chodzi o żadne systemowe zmiany, prowadzące do uregulowania pluralistycznego charakteru takich mediów, ale położony jest nacisk na pragmatyczne i doraźne cele propagandowe nowej władzy ${ }^{9}$. W związku z tym pojawiają się w wypowiedziach posłów opozycji w związku z tym sformułowania o „odwecie” i „zemście”, „łupie” nowej władzy i „brance”, centralizacji zastępującej decentralizację.

Wskazuje się tu na cynizm władzy, która w imię rewolucyjnych haseł i sloganów o narodowym charakterze mediów tworzy w sposób jawny i bez żadnych oporów konstrukcję mediów partyjnych i rządowych, służących wyłącznie celom politycznym.

\footnotetext{
9 Pojawiające się w debacie sejmowej, głównie przez posłów opozycji zarzuty celów propagandowych PiS dotyczą przede wszystkim zabiegów tej partii do stosowania jednokierunkowej komunikacji (nie interaktywnej i wielokierunkowej). Związane to jest przede wszystkim z brakiem jakichkolwiek konsultacji i uzgodnień dotyczących samego projektu, pośpiechu z jego uchwaleniem, brakach legislacyjnych itp., ale też ignorowaniu jakichkolwiek ocen płynących ze strony opinii publicznej. Politycy PiS powoływali się przy okazji tej ustawy i innych na wolę narodu i suwerena wyrażoną w wyborach, która dała im legitymację do stosowania tak fundamentalnych zmian.
} 
W związku z tym w niektórych wypowiedziach opozycji pojawia się wyraźnie wątek odwetu, do którego zmierzają działania PiS, ale dokonanego ze względu na zaniedbania systemowe całej klasy politycznej z przeszłości dotyczące także mediów publicznych. Podnoszone oskarżenia na temat zemsty i odwetu przybiera często formę wendety, zmierzającej wprost do budowania mediów partyjnych jednej partii.

W bardzo wielu wystąpieniach opozycji pojawia się motyw nazwania nowego projektu zmiany dążeniem do ustanowienia mediów rządowych, a nie narodowych. W odniesieniu do nowej regulacji pojawia się zarzut, że nie jest to tworzenie nowej ustawy medialnej, ale „protezy” legislacyjnej, która służy wyraźnym celom politycznym. Przez protezę rozumiane tu są rozwiązania uważane za przejściowe, które stosowane są wyłącznie dlatego, aby doprowadzić do odwołania poprzedników i zastąpienia ich zwolennikami nowej władzy.

Następna kategoria argumentacyjna interpretuje działania PiS jako sprzeczne z procedurami demokratycznymi, przez które można rozumieć po pierwsze odstąpienie od konsultacji społecznych i środowiskowych dotyczących zmian w mediach, po drugie likwidację formuły konkursowej dotyczącej wyboru władz radia i telewizji.

Ten kierunek myślenia i retoryki rozdziela się jeszcze na dwa nurty, całkowicie sobie przeciwstawne. Pierwszy, to ten wieszczący ostateczny koniec formuły i praktyki mediów publicznych. Ma przesądzać o tym rynek zdominowany przez komercjalizację (wpływy z reklam jako podstawa finansowania i dostosowana do tego oferta programowa), który jest obecny także w mediach publicznych od ich powstania na początku lat 90. zeszłego wieku. Dodatkowym, ale decydującym faktem jest natomiast zmiana dotychczasowych mediów, zwanych publicznymi na media rządowe. Dokonanie takiej zmiany bez pozorów, w pośpiechu, bez konsultacji i debaty jest wystarczającym dowodem na intencje władzy, która dąży do unicestwienia dotychczasowego, nieidealnego może i nieefektywnego modelu publicznych nadawców. 
Druga, zasadniczo odmienna tendencja, obecna w wypowiedziach wielu polityków i ekspertów to przekonanie, że nawet jeśli ta zmiana nie jest zgodna z tą, która była zapowiadana i oczekiwana, te przeprowadzone niedoskonałe rozwiązania są i tak lepsze niż te praktyki, które stosowano dotychczas. Taki typ stosowanej retoryki ogniskuje się w stwierdzeniach o polskich mediach narodowych, a uwaga koncentrowana jest na tych, którzy te media poprzednio tworzyli i muszą odejść zgodnie z pewnego rodzaju poczuciem sprawiedliwości dziejowej. Jeśli nawet ci, którzy media w wyniku zmiany przejęli, nie są profesjonalistami, to i tak są lepsi niż przedstawiciele poprzedniej ekipy, są bardziej „swoi’ niż „obcy” z ekipy poprzedniej. I co za tym idzie, rządowy model mediów publicznych jest koniecznym etapem przejściowym w wyniku tak radykalnej transformacji, jaką docelowo mają być media prawdziwie narodowe, patriotyczne i polskie.

Model nostalgiczny: media obywatelskie

Na marginesie tych dwóch najbardziej reprezentatywnych wątków sytuuje się nurt myślenia, zakładającego konstrukt, który kładzie nacisk na „obywatelskość” mediów publicznych. Ten nurt też nie jest jednorodny i narodził się, przed kilku laty w środowiskach organizacji pozarządowych i sektora obywatelskiego, które opracowywały alternatywny do istniejącego projekt mediów publicznych. Przeważnie przez obywatelski charakter mediów środowiska te rozumieją po prostu ich pluralizm w sensie kształtowania oferty, przekazu dla opinii publicznej i demokratycznego sposobu zarządzania i wyłaniania kadry menedżerskiej. Obywatelskość mediów przeciwstawiana jest najczęściej dominującemu w poprzednim typie dyskursywnym, dwubiegunowemu obrazowi sytuacji polegającego na walce „nowego” ze „starym”. Jest to swego rodzaju „trzecia droga” wzorowana na wspomnianym już wcześniej modelu mediów publicznych BBC. 
Mamy tu więc do czynienia z postulatem rozszerzenia nadzoru na działalność nad mediami publicznymi na środowiska kultury, artystyczne, wielu środowisk twórczych, naukowe i akademickie. Pod wpływem takiego założenia, media publiczne są częścią społeczeństwa obywatelskiego, a nie państwa na co $\mathrm{w}$ wielu wystąpieniach powołują się działacze PiS. Jest to jedna z fundamentalnych różnic w myśleniu o tych mediach, dzieląca obecną władzę i opozycję.

Jeszcze inni politycy chcieliby odebrania mediów publicznych politykom, przede wszystkim PiS i PO, czyli tym którzy sprawują władzę i ją poprzednio pełnili. Następuje tu odwołanie się wprost do projektu obywatelskiego sprzed lat, która miała na celu oddanie nadzoru nad mediami ciału kolektywnemu, wyłanianemu z porozumienia środowisk twórczych, dziennikarskich i artystycznych, akademickich i naukowych, organizacji pozarządowych i instytucji obywatelskich ${ }^{10}$. Nigdy ten projekt nie doczekał się szerszej konsultacji politycznej, prowadzonej przez partie w parlamencie, a tym samym nie wszedł do procedury legislacyjnej.

Ta ostatnia opinia ma zresztą charakter pewnej niespełnionej tęsknoty aby media publiczne były integralną częścią społeczeństwa obywatelskiego, a nie sfery polityki i obszaru gospodarczego. W tym sensie społeczeństwo powinno mieć wpływ na media, które są jego integralną częścią, wypreparowaną z jednej strony od rynku, z drugiej od uwarunkowań politycznych.

Interesujące wypowiedzi, oparta na tego rodzaju argumentacji dotyczą diagnozy pozycji i kondycji dziennikarstwa i dziennikarzy. Odnoszą się one do opozycji media partyjne - obywatelskie, ale uwaga skupiona

\footnotetext{
${ }^{10}$ Chodzi w tym przypadku o działania prowadzone od czasu odbywającego się w 2009 roku Kongresu Kultury, w wyniku którego ukonstytuował się Komitetu Obywatelskiego Mediów Publicznych. Wskutek jego działań podpisano w 2011 z ówczesnym rządem PO i PSL „Pakt dla kultury”, którego częścią miały być działania dotyczące wypracowania nowej koncepcji mediów publicznych i społecznego wyłaniania władz tychże mediów. Te działania nie doczekały się realizacji. Por. Ogólnopolska Federacja Organizacji Pozarządowych 2016.
} 
tu jest przede wszystkim na dziennikarzach. Przywoływany jest wielokrotnie powtarzający się motyw dziennikarzy jako „funkcjonariuszy partyjnych”, „kasty dziennikarzy partyjnych”, niezależnie od opcji i partii politycznej.

Co jest charakterystyczne, to często pojawiające się konkluzje o „mediach polskich" w sytuacji kiedy obywatelskie media są niemożliwe w racji zepsucia systemu przez upolitycznienie i upartyjnienie ${ }^{11}$. To jest inny wariant prezentowania opozycji, o której mowa była już wcześniej: media wolne-partyjne, niezależne-rządowe, publiczne-narodowe. Ale retoryka odnosząca się do mediów polskich to był też początek szerzej zamierzonych planów i działań PiS oraz niektórych środowisk narodowych, podejmowanych już w 2017 roku, a dotyczących tzw. repolonizacji mediów i ich dekoncentracji. Chodzi przede wszystkim o dokonanie takich zapisów legislacyjnych, w oparciu o które możliwe byłoby dokonanie takiej zmiany właścicielskiej w mediach komercyjnych, aby większościowy kapitał należał do polskich właścicieli.

Często wyrażany jest pogląd, że wprowadzane zmiany systemowe, z sferze zarządzania mediami, czy te wyraźnie personalne będą miały wpływ na zagwarantowane obywatelom w konstytucji podstawowe wolności. W nawiązaniu do rozwiązań systemowych, tych obecnych i tych kształtowanych ewolucyjnie przez okres ponad dwudziestu lat pojawia się zestawienie działań decentralizacyjnych - i to może być kolejna wersja obywatelskości - i centralizacyjnych, utożsamianych z mediami państwowym i rządowymi. Wydaje się, że te działania przeciwstawne sobie, czyli relacja między zdecentralizowanym rynkiem i centralistycznymi zapędami nowej władzy doprowadzić mogą do ostatecznej klęski mediów publicznych, wieszczonej zresztą od kilku lat.

\footnotetext{
"Dość spektakularny postulat w tym zakresie pojawił się w czasie wysłuchania publicznego dotyczącego dużej ustawy medialnej w Sejmie. Według relacji z tego spotkania padły tam oskarżenia o antysemityzm. Sprowokowała je wypowiedź szefowej stowarzyszenia Solidarni 2010 Ewy Stankiewicz, która zaproponowała wpisanie w ustawie do misji publicznej mediów narodowych „kultywowanie wartości chrześcijańskich". Jak mówiła „dla potomków osób pełniących obowiązki Polaka" może być to trudne do przyjęcia, że Polska jest krajem chrześcijańskim i katolickim (kg/kk 2016).
} 
Zademonstrowane $\mathrm{w}$ tej analizie różnego typu poglądy na sprawę mediów publicznych siłą rzeczy powinny być konfrontowane z szerszym kontekstem ich występowania, w szczególności z innymi działaniami podejmowanymi przez obóz władzy. Była już o tym mowa na wstępie tego tekstu. Po pierwsze, ta sekwencja różnych działań legislacyjnych podporządkowana jest radykalnemu programowi zmian założonych przez PiS w sferze wymiaru sprawiedliwości, wojska, oświaty, systemu ubezpieczeń społecznych i systemu zdrowotnego, programów socjalnych i rozwojowych. Integralnym elementem tych zmian są media publiczne. I po drugie, te właśnie media mają stanowić „osłonę” propagandową dla tego typu działań i akceptacji społecznej dla nich, wykraczającą poza żelazny elektorat PiS i podporządkowaną pozyskaniu zwolenników centrowych i lewicowych.

Konkluzja

Pierwszą refleksją, która pojawia po przeprowadzonej analizie jest to, że podobnie jak w wypowiedziach posłów podczas kluczowej debaty medialnej w parlamencie, wielu polityków i ekspertów, dziennikarzy i komentatorów w tym okresie sytuowało się w wyraźnie sfragmentaryzowanych przestrzeniach dyskursywnych podzielonych według schematów ideologicznych. Dlatego też, według identycznych schematów dyskursywnych jak to było w przypadku debaty parlamentarnej przebiegały wypowiedzi osób, które zabierały głos w debacie publicznej na temat mediów publicznych, głównie pod koniec 2015 roku oraz w roku 2016, a także 2017. Można więc przyjąć, że te trzy modele: model rewolucyjny „dobrej zmiany”, model zemsty i odwetu oraz model mediów obywatelskich, generowane były przez odpowiadające im wyraźne schematy ideologiczne, nawiązujące do myślenia w kategoriach narodowych, liberalnych i lewicowych. Do nielicznych należały wypowiedzi nawiązujące do procesów globalnych, jak na przykład refleksje o mediach publicznych 
wpisujących się w ideę i formułę mediów wysokojakościowych (Mistewicz 2015) ${ }^{12}$.

Ale są i inne spostrzeżenia i wnioski, bowiem analizując materiały dotyczące dyskursu publicznego w czasie dokonywania zasadniczej zmiany w ich funkcjonowaniu w polskim systemie medialnym w zdecydowanej większości wypowiedzi nieodparcie przebijało się przekonanie o dwóch podstawowych sprawach. Po pierwsze, o niedoskonałości stanu tych mediów w momencie zmiany politycznej w 2015 roku, po drugie o braku skutecznej recepty na dokonanie zmiany tej sytuacji. Ten pesymistyczny wątek diagnozy i prognostyczny przejaw bezradności stworzył ramy do wyrażania, tak zachowawczych, jak i radykalnych, a przy okazji i kontrowersyjnych opinii i ocen. Pewien ich zbiór, wybranych z punktu widzenia najbardziej prawdopodobnej reprezentatywności został zamieszczony w tym rozdziale.

Podnoszony tu fatalizm co do diagnozy i prognozy związany jest prawdopodobnie z poczuciem pragmatyzmu politycznego. Najkrócej rzecz ujmując, w ciągu prawie trzydziestu lat demokracji w Polsce żadnej sile politycznej nie opłacało się przeprowadzić radykalnej reformy związanej z nadawcą publicznym ze względu na możliwe do poniesienia straty wizerunkowe i polityczne.

Z punktu widzenia przeprowadzonej tu analizy dyskursu mamy do czynienia z przyjęciem postawy, a zarazem formuły retorycznej przypisanej do bycia stroną rządową lub opozycją w najbardziej typowym tego wydaniu: $\mathrm{z}$ jednej strony cynicznym przedstawianiem sytuacji przejmowania mediów publicznych z punktu widzenia obrony interesu narodowego, z drugiej strony graniczącym z hipokryzją występowaniem w imieniu interesu społecznego - lub obywatelskiego - w obronie me-

12 Z kolei pierwszą połowę roku 2017 zdominowały opinie i oceny dotyczące przyjęcia nowych rozwiązań związanych z płaceniem abonamentu radiowo-telewizyjnego, w szczególności usprawnienia procesu ściągalności tego abonamentu. 
diów publicznych. W obu przypadkach te postawy i zachowania pozbawione są wiarygodności z punktu widzenia opinii publicznej: w pierwszym chodzi o efekt działania bez zachowania pozorów (decyzje PiS podejmowane w nocy, przy pustych ławach rządowych, bez konsultacji, przed sylwestrem), w drugiej bez zachowania przyzwoitości (krytyka kierowana pod kątem opozycji z PO, dotycząca niechęci do podjęcia jakichkolwiek istotnych zmian wcześniej, podczas osiem letnich rządów tej partii). I to jest być może powód tego, dlaczego ta właśnie opinia publiczna - podzielona i z tego powodu fragmentaryczna - zachowuje dość dużą rezerwę do przeprowadzanych spraw, w przeciwieństwie do przedstawionych na początku tego tekstu opinii instytucji międzynarodowych i instytucji europejskich, które krytycznie odnoszą się do oceny zmienianych ustaw medialnych. Bardzo wymowna w tym zakresie jest jedna z wypowiedzi Jacka Żakowskiego „Nie mam zamiaru bronić TVP, bo to jest porażka wolnej Polski. Ale PiS chce tę porażkę zamienić w katastrofę. Przeciw temu trzeba protestować. (...) Dla obywatela lepszy jest taki kulawy wróbel, jak TVP, w garści, niż PiS-owski paw mediów narodowych na kościelnym dachu. (...) Po ćwierć wieku konsekwentnego głodzenia przez państwo media publiczne stały się komercyjnie imponująco sprawne. I właśnie za to płacą. Bo ceną było faktyczne porzucenie misji i zmarnowanie szansy przyczynienia się do powstania w Polsce świadomego demokratycznego społeczeństwa obywatelskiego, które m.in. rozumie to, czego nigdy nie zrozumieli polscy politycy - jak kluczową rolę gra w demokracji budowanie i podtrzymywanie kultury demokratycznej. W europejskich stabilnych demokracjach to właśnie - obok wyznaczania standardów jakościowych dla całego rynku medialnego jest główny cel i sens istnienia mediów publicznych" (Żakowski 2016).

Powstaje niekiedy wrażenie, o czym świadczy większość zaprezentowanych wypowiedzi, zwłaszcza polityków, że mamy znowu do czynienia ze spektaklem, gdzie aktorzy, będący i odgrywają swoje polityczne role wobec elektoratu, a daleko w tle pozostaje interes społeczny związany 
z głównymi przesłaniami granego spektaklu. Brzmi to nieco populistycznie, ale coraz częściej - i potwierdza to szereg zawartych w tym tekście wypowiedzi - mamy do czynienia z płomiennym demonstrowaniem przez polityków, ale i ekspertów i komentatorów oraz dziennikarzy poglądów, które wynikają z wyreżyserowanego projektu, zakładającego pożądany wpływ na opinię publiczną. I dlatego sytuowanie się w sfragmentaryzowanym schemacie sfery publicznej jest zabiegiem i ideologicznie uzasadnionym ze względu na interes społeczny i pragmatycznie zalegitymizowanym z punktu widzenia politycznych preferencji.

Ale niezależnie od tej dość niepochlebnej dla elit politycznych oceny, tak jak to jest w przypadku każdego modelowego analizowania zjawisk mamy tu do czynienia tylko w pewnymi schematami myślenia, które nie odzwierciedlają w pełni wyczerpanego zbioru rzeczywistych czynników, przesądzających o dokonywanych zmianach. Przestrzeń między opiniotwórczymi elitami, a faktyczną, bardzo niejednorodną opinią publiczną jest na tyle szeroka, że mogą w niej występować rozmaite inne sposoby identyfikowania rzeczywistości niż tylko te, które wynikają z przeprowadzonych badań. Nie można jednak ich bagatelizować, bowiem w oparciu o nią kształtowane są postawy i zachowania ludzi, które skutkują także - obok wskaźników oglądalności i słuchalności, a może przede wszystkim - wynikami wyborów.

Bibliografia

Brzezicki Ł. (2016), Barbara Bubula: duża ustawa medialna już gotowa, mała nowelizacja ma uspokoić sytuacje, Portal wirtualnemedia.pl, https://www.wirtualnemedia.pl/artykul/barbara-bubula-du za-ustawa-medialna-juz-gotowa-mala-nowelizacja-ma-uspokoicsytuacje/page:2 
Czyżewski M. (1997), W stronę teorii dyskursu publicznego, w: Czyżewski M., Kowalski S., Piotrowski A. Rytualny chaos. Studium dyskursu publicznego, Wydawnictwo Aureus, Kraków

Czyżewski M., Kowalski S., Piotrowski A. (1997), Wprowadzenie, w: Czyżewski M., Kowalski S., Piotrowski A. Rytualny chaos. Studium dyskursu publicznego, Wydawnictwo Aureus, Kraków

Dijk T. van (1997), The Study of Discourse, w: Discourse as Structure and Process: Discourse Studies: A Multidisciplinary Introduction (ed.) Dijk T. van, SAGE, Thousand Oaks

Dobek-Ostrowska B. (2010), System partyjny a media $w$ Polsce - zależności i relacje, „Studia Medioznawcze” nr 2

Foucault M. (1977), Archeologia wiedzy, PIW, Warszawa Jakubowicz K. (2008), Finding the Right Place on the Map: Prospects for Public Service Broadcasting in Post-Communist Countries, w: Finding in Right Place in the Map: Central and Eastern European Media Change in the Global Perspective, (eds.) Jabubowicz K., Sükösd M., Intellect Books, Bristol

Janicki M., Władyka W. (2009), Ale to już było, „Polityka” nr 34 (2719) kg/kk (2016), „Potomkowie osób petniących obowiązki Polaka”. Burza na posiedzeniu komisji, Portal tvn24, http://www.tvn24.pl/wiadomosci-z-kraju,3/ewa-stankiewicz-o-potomkach-osob-pelniacych-ob owiazki-polaka,644612.html

Lisowska-Magdziarz M. (2006), Analiza tekstu $w$ dyskursie medialnym, Wydawnictwo Uniwersytetu jagiellońskiego, Kraków

Media and Politics in New Democracies. Europe in a Comparative Perspective (2015), (ed.) Zielonka J., Oxford University Press, Oxford

Media Reform. Democratizing the media, democratizing the state (2002), (eds.) Price M.E., Rozumiłowicz B., Verhulst S.G., Routledge, London-New York 
Media $w$ Polsce. Do kogo należy prasa, telewizja, portale czy radio? (2016), Portal money.pl, http://www.money.pl/gospodarka/wiadomosci/artykul/media-w-polsce-do-kogo-nalezyprasa,138,0,1988746.html

Mistewicz E. (2015), Nie likwidujcie mediów publicznych, „Rzeczpospolita" nr 277

Ogólnopolska Federacja Organizacji Pozarządowych (2016), Stanowisko sygnatariuszy Paktu $w$ sprawie projektów ustaw medialnych, https://ofop.eu/aktualnosci/stanowisko-sygnatariuszy-paktu-w-sp rawie-projektow-ustaw-medialnych

oprac. Bereźnicki J. (2017), Jacek Kurski bierze 800 mln zt kredytu w BGK. Tak ratuje finanse TVP po zamrożeniu uszczelnienia abonamentu, Portal money.pl, https://www.money.pl/gospodarka/wiadomosci/ar tykul/tvp-kredyt-bgk-80o-mln-zl-jacek-kurski,36,0,234090o.html Pallus P. (2017), Największe kanaly tracq widzów. Polsat i TVN uciekaja TVP, Portal Business Insider Polska, http://businessinsider. com.pl/media/tv-radio/polsat-tvp-i-tvn-ogladalnosc-stacji-tv-w-kw ietniu-2017-roku/2etk7qk

Pokorna-Ignatowicz K. (2010), Telewizja publiczna jako „up polityczny”, „Studia Medioznawcze” nr 2

Program Prawa i Sprawiedliwości 2014 (2014), http://pis.org.pl/document/archive/download/128

Public Service Media in Europe: A Comparative Approach (2015), (eds.) Arriaza Ibarra K., Nowak E., Kuhn R., Routledge, Abingdon Rutkowska E. (2015), PiS zapowiada reformę mediów publicznych $i$ zmianę prawa prasowego, Portal press.pl, https://www.press.pl/ tresc/40255,pis-zapowiada-reforme-mediow-publicznych-i-zmiane -prawa-prasowego

Sejm RP (2015), Sprawozdanie Stenograficzne z 7. posiedzenia Sejmu Rzeczypospolitej Polskiej w dniu 29 grudnia 2015 r. (pierwszy dzień obrad), 
Warszawa, http://orka2.sejm.gov.pl/StenoInter8.nsf/o/8AD723BB 67E57043C1257F2Ao055265E/\%24File/o7_a_ksiazka_bi.pdf

Sejm RP (2015a), Sprawozdanie Stenograficzne z 7. posiedzenia Sejmu Rzeczypospolitej Polskiej w dniu 30 grudnia 2015 r. (drugi dzień obrad), Warszawa, http://orka2.sejm.gov.pl/StenoInter8.nsf/o/2263B5 8F2F7A96BAC1257F2Boo5F2297/\%24File/o7_b_ksiazka_bis.pdf Śpiewak P. (2010), Dlaczego wymyślitem IV RP, „Polityka Cyfrowa” 29 czerwca, http://www.polityka.pl/tygodnikpolityka/kraj/1506800,1, dlaczego-wymyslilem-iv-rp.read

Telewizja publiczna $w$ Europie [INFOGRAFIKA] (2016) Portal Onet wiadomości, https://wiadomosci.onet.pl/telewizja-publiczna-w-europie-infografika/rmq47r

tw (2017), Firmy medialne skarżą do Komisji Europejskiej nowelizacje abonamentu rtv, Portal wirtualnemedia.pl, https://www.wirtualnemedia.pl/artykul/nowelizacja-abonamentu-rtv-firmy-telekomunikacyjne-skarza-do-komisji-europejskiej

tw (2017a), GIODO o nowelizacji ustawy abonamentowej: pozyskiwanie danych klientów płatnej to oznacza zmianę warunków ich umów, Portal wirtualnemedia.pl, http://www.wirtualnemedia.pl/ artykul/ustawa-abonamentowa-2017-abonament-rtv-opinie-giodoklienci-platnej-telewizji

Wnuk M. (2016), Media publiczne - obywatelskie czy narodowe? Najnowszy dyskurs parlamentarny o mediach $w$ kontekście zmian $w$ ustawie o radiofonii i telewizji, „Studia Medioznawcze” nr 3 (66) Żakowski J. (2016), Jacek Żakowski o polskich mediach: od porażki do katastrofy, Portal wp.pl, https://opinie.wp.pl/jacek-zakowski-opolskich-mediach-od-porazki-do-katastrofy-6016711021650561a 